\title{
ATATÜRK \\ VE \\ YABANCI GÖZÜYLE BİZE BIRAKTIĞI MİRAS
}

\author{
Doç.Dr. Sema ÇIĞDEMOĞLU
}

\begin{abstract}
“Atatürk Inkılabın ruhu, İstiklal Savaşının ruhu olmuştu, diyor Jean-Paul Roux, sert iradesi sayesinde yıkalmakta olan büyük bir milleti yaşama gücüne kavuşturmuş, tıpk bir heykeltraş gibi onu elleriyle biçimlendirmiş tamamen yeni bir yüz vermiş, varlığının bilincini idrak ettirmiş ve geleceğe ümitle bakmasını sağlamıştı."
\end{abstract}

Bilindiği gibi 15 Mayıs 1919 da Yunanlılar İzmir'e çıkmıştır. Başka bir yazar durumu şöyle anlatıyor.

“15 Mayıs 191912000 den fazla Yunanlı Izmir'e çıkıyor. Müttefikler bu harekatı, müttefik donanmasının kontrolünde basit bir polis işi olarak öngörüyorlar. Oysa dağınık Yunanlı halk tarafından sevinç içinde karşılanan bu yunan güruhunun ele aldığı gerçek bir mücadeledir. Sabahın son saatlerinde, Yunanlıların Türk kışlasının önünden geçtiği sırada bir ateş sesi duyuluyor. Sforza ve Yunanlilara düşman olanlar bir Yunanlı kışkırtıcı casustan şüpheleniyorlar. Fakat durumu Türkler üstleniyor. İzmir'li gazeteci Hasan Tahsin'e malediyorlar: “Türkler ölmedi, yaşıyor... ve bu şehri Yunanlılara vermiyecekler. Bu bir yaylım ateşinin işaretidir. Katliamlar başlıyor. Bir Fransız subayının ilk bilançosuna göre 300 Türk ceset. Yunan ateşi Izmir'i taşıyor: askeri birlikler, cinayetler, yangınlar, yağmalar ve tecavüzler artiyor."

15 Mayıs 1970 tarihli "Yeni Asır" (İzmir) gazetesinde aşağıdaki satırları okuyoruz.

“15 Mayıs 1919... Izmir' in en karagünü. Sabahın erken saatlerinden itibaren Birinci Kordonda hummalı bir faaliyet var. Körfezdeki savaş gemileri namlularını Kadifekale'ye çevirmiş. Az sonra sapık bir ideolojinin öncüleri "Zito" çı̆̆lıkları arasında sahile çıkmaya başladılar. Rumlar sevinç ve zafer naralan atarken Türklerin gözleri nemli, dişleri kenetli... Her şey yolunda, yordamında. Yalnız hesapta olmayan bir şey var. $\mathrm{O}$ da Türk'ün tutsak edilemeyeceği. Hele hele kendi öz yurdunda. Yunan Ordusunun Izmir'e çıktığını Samsun yolunda duyan Mustafa Kemal, "Geldikleri gibi

1. Jean-Paul Roux, La Turquie, Geoğraphie, Economie, Histoire Civilisation et Culture. Payot Paris 1953, s. 125

2. Alexandre Jevakhoff, Kemal Atatürk. Tallandier, Paris 1989, s.100. 
giderler"l demişti. Ne var ki yanılmıştı bu sözlerinde. Gelenler geldikleri gibi gitmeye hatta kaçabilmeye çoktan razı oldular, fakat fırsatını bulamadılar. 9 Eylüll 1922 sabahı Birinci Kordon'da çınlayan nal sesleri Türk'ün zaferini bütün dünyaya ilan ederken 3 yıl içinde büyük debdebe içinde gelenler kaçacak birer delik anyordu. Izmir'in körfezi çoğuna mezar oldu."

Mustafa Kemal Paşa'nın Samsun'a çıkışı hakkında Paul Gentizon şöyle diyor. (Söyledikleri)

"Bu son yıllarda Mustafa Kemal'in kişiliği bütün Türkiye tarihini doldurmaktadır. Mayıs 1919 gününden beri, Sultan'ın ve Osmanlı İmparatorluğu namussuzluklarına dayanamayan Mustafa Kemal, Osmanlı Imparatorluğu yerine milli bir devlet kurmak için, İstanbul'u terkediyor ve Samsun'a ç1kyyor. Askeri başarlar, politik ihtilaller, toplumsal reformlar hepsi onun eseridir. Bütün sahalarda ve en kritik durumlarda, takip edilecek yolu her seferinde o çizmiş ve uygulamayı yönetmiştir."”

19 Mayıs 1919 da Mustafa Kemal'i kendi sözleriyle dinleyelim.

“1919 senesi Mayısının 19 ncu günü Samsun'a çıktım. vaziyet ve manzarai umumiye:

Osmanlı Devleti'nin dahil bulunduğu grup, Harbi Umumide mağlup olmuş, Osmanlı ordusu her tarafta zedelenmiş, şeraiti ağır, bir mütarekename imzalamış. Büyük Harbin uzun seneleri zarfında, millet yorgun ve fakir bir halde, Millet ve memleketi Harbi Umumiye sevkedenler, kendi hayatları endişesine düşerek, memleketten firar etmişler. Saltanat ve hilafet mevkiini işgal eden Vahdettin, mütereddi, şahsını ve yalnız tahtını temin edebileceğini tahayyül ettiği yeni tedbirler araştırmakta. Damat Ferit Paşa'nın riyasetindeki kabine; aciz, haysiyetsiz, cebin, yalnız padişahın iradesine tabi ve onunla beraber şahıslarını vikaye edebilecek herhangi bir vaziyete razı.

Ordunun elinden esliha ve cephanesi alınmış ve alınmakta...

Itilaf Devletleri, mütareke ahkamına riayete lüzum görmüyorlar. Birer vesile ile, Itilaf donanmaları ve askerleri Îstanbul'da. Adana vilayeti, Fransızlar, Urfa, Maraş, Ayıntap, Ingilizler tarafından işgal edilmiş. Antalya ve Konya'da, Italyan kataatı askeriyesi; Merzifon ve Samsun'da Ingiliz askerleri bulunuyor. Her tarafta, ecnebi, zabit ve memurlan ve hususi adamlan faaliyette.

Nihayet mebdei kelam kabul ettiğimiz tarihten dört gün evvel, 15 Mayıs 1919 da Itilaf Devletlerinin muvaffakiyetiyle Yunan Ordusu Izmir'e ihraç ediliyor.

Bundan başka, memleketin her tarafında, anasırı hıristiyane hafi, celi, hususi emel ve maksatlarının temini istihsaline, devletin bir an evvel çökmesine sarfi mesai ediyorlar.

Bilahare elde edilen mevsuk malumat ve vesaik ile teeyyüt etti ki, İstanbul Rum Patrikhanesinde teşekkül eden Mavri Mira heyeti, vilayetler dahilinde çeteler teşkil ve idare etmek, mitingler ve propagandalar yaptırmakla meşgul. Yunan Salibiahmeri, resmi muhacirin komisyonu; Mavri Mira hep.338.

3. Paul Gentizon, Mustafa Kemal ou l'Orient en Marche Bossard, Paris 1929, 
yetinin teshili mesaisine hadim. Mavri Mira heyeti tarafından idare olunan Rum mekteplerinin izci teşkilatlan, yirmi yaşını mütecaviz gençler de dahil olmak üzere her yerde ikmal olunuyor.

Ermeni Patriği Zaven Efendi de, Mavri Mira heyetiyle hemfikir olarak çalışıyor. Ermeni hazırlığı da tamamen Rum hazırlığı gibi ilerliyor.

Trabzon, Samsun ve bütün Karadeniz sahillerinde teşekkül etmiş ve Istanbul'daki merkeze merbut Pontus Cemiyeti sühuletle ve muvaffakiyetle çalışıyor."

22 Haziran 1919 Amasya tamimini, 23 Temmuz - 4 Ağustos Erzurum Kongresi takip eder. Kongre kararlarından bazıları şunlardır:

Hududu milliye dahilinde bulunan bilcümleaksamı vatan bir küldür. Yekdiğerinden infikale kabul etmez.

Her türlü ecnebi işgal ve müdahalesine karşı ve Osmanlı Hükümetinin inhilali halinde millet müttehiden müdafaa ve mukavemet edecektir.

Kuvayi milliyeyi amil ve iradei milleyeyi hakim kılmak esastır.

Manda ve himaye kabul olunamaz.

Mustafa Kemal 29 Ağustos'ta Erzurum'dan ayrilır. 2 Eylül'de Sivas civarına varır.

İşte bir yabancı yazarın yorumu:

“1919 Eylül'ünde Mustafa Kemal Rumeli ve Anadolu Müdafaa-i Hukuk Cemiyetinin toplandığı Sivas Kongresinin başkanı olarak seçildiğinde (daha sonra bu kongre Büyük Millet Meclisi'nin kurulmasına neden olacaktır) üstlendiği en acil görev büyük güçler ve komşuları tarafından kabul edilen sınırlar içinde bir Türk Devleti kurmaktı. O zaman için imkansız görülen bu görev, büyük savaşın galipleri ve Osmanlı padişahınınhükümetine rağmen aslında tam üç yıl sonra gerçekleşti.

Ta başlangıçta Mustafa Kemal ve Kongre, ilk maddesi esas olan "Pacte National" (Milli Antlaşma) içindeki çalışmalarının amaçlarını belirlemişlerdi. 30 Ekim 1918 (Mondros Mütarekesi) tarihinde müttefikler tarafından işgal edilmiş Osmanlı toprakları bölünmez ve ayrılmaz bir bütün olarak kabul edilmişti. İsgal altındaki bölgelere gelinince, çoğunlukla halkı araplardan olusuyordu. Kendi kaderlerini tayin etme hakkına sahiptiler ve yeni kurulan Türkiye'nin hiç bir şekilde müdahale etmesi söz konusu değildi. Bu bir kaç satır hiç bir şüpheye yer bırakmaksızın yeni devletin talep ettiği topraklan belirliyordu; Trakya'dan Anadolu'ya uzanan ve halkının çoğunluğunu Türklerin oluşturduğu geniş bir dikdörtgen. Bunun varlığını ve meşruluğunu diğer ülkelere kabul ettirebilmek için büyük çaph askeri çaba harcanması kaçınılmazdı. Bu askeri çabanın sonuçlarından sürekli ve ustaca diplomatik bir hareketle yararlanıldı."

4. Gazi Mustafa Kemal, Nutuk-Söylev, Türk Tarih Kurumu Basımevi, Ankara 1989, I.Cilt, s.2.

5. Jean-Louis Bacque-Grammont, Jean Paul Roux, Mustafa Kemal Atatürk et la turquie nouvelle. Maisonneure et Larose, Paris 1982, p.45. 
4-11 Eylül 1919 da Sivas Kongresi yapılmısştır. Erzurum Kongresi'nde, kuruluşun adı "Vilayatı Şarkiye Müdafaai Hukuku Milliye Cemiyeti" iken Sivas Kongresi'nde, bütün yurdu kapsayacak "Anadolu ve Rumeli Müdafaai Hukuk Cemiyeti" olmuştur. Bu kongrede seçilen "Heyeti Temsiliye" 27 Aralık 1919 da Ankara'ya gelerek T.B.M.M.'nin açılışına kadar çalışmıştır.

27 Aralık 1919 Mustafa Kemal Paşa'nın Ankara'ya gelişini, 19191921 iç ayaklanmalan, 15 Mart 1920 İstanbul'un işgalini, 23 Nisan 1920 T.B.M.M.'nin açılışını takiben 10 Ağustos 1920 'de Sevr anlaşması imzalanmıştır.

İşte yine bir yabancı yazarın görüşleri:

"Yenilgiyle yıkılmış, Sevr antlaşması'ndaki parçalanma ile ilgili, müttefiklerin başarısının tehdidi altında, 1922 de Yunan saldırısını tertipleyen Ingilizlerin öfkesi üzerinde, eğer Mustafa Kemal gibi hayran olunacak bir kahraman, bir kurtarıcı, serefli bir asker, önemli bir devlet adamı ortaya çıkmasaydı şüphesiz Türkiye çökerdi. Mustafa Kemal Türk milliyetçiliğini coşturmuş, ordular kurmuş, onlara layık subayları başa getirmiş, istilacı Yunanı bozguna uğratıp, Sakarya'da ezmiş ve böylece milli hürriyeti sağlamıştır. 1922 Lozan Antlaşmasıyla, Mustafa Kemal Türkiye'yi politik ve moral yönden huzura kavuşturmuştur. Bundan sonra çağdaş değişimlere uygun bir Türkiye yaratmak için bütün gayretini sarfetmiştir."

Osmanlı Devleti ile İtilaf Devletlerinin taraf olduğu Sevr Antlaşması'ndaki başlıca şartlar şöyle idi:

- Sinırlar (haritada görülmektedir).

- Kürdistan ve Ermenistan devletleri kurulacaktır.

- Fransız ve Ittalyan iktisadi nüfuz bölgeleri kurulacaktır.

- Istanbul'un bizden alınması da söz konusudur.

- Türk uyrukluğundan çıkacaklara Türk hükümeti engel olmayacaktır.

- Adli kapitülasyonlar yeniden düzenlenecektir.

- Azınlıklara geniş haklar verilecektir.

- Türk Silahlı Kuvvetlerinin insan ve silah sayısı büyük ölçüde azaltılmıştrr. Itilaf Devletleri kara, deniz ve hava kontrol komisyonları kuracaklardir; silah ve cephane kendilerine teslim edilecektir.

- Harp suçlusu sayılanlar Itilaf Devletlerine, Yunanistan ve Ermenistan'a teslim edilecektir.

- Itilaf Devletleri bir Maliye Komisyonu kurarak, bütçeyi denetleyecek, Türkiye'nin bütün gelirlerini emrinde tutacak, Itillaf ordularının işgal masraflarını ödeyecektir. Vb.

- Kapitülasyonlar yeniden verilecek, Yunanistan ve Ermenistan da bunlardan yararlanacaktır.

- Boğazlar için komisyon kurulacak; komisyonda Amerika, Ingiltere, Fransa, Italya, Japonya ve Rusya oy sahibi olacaklardır.

6. Albert Sarraut, Mon Ambassade en Turquie, 27 Şubat 1953, Belediye Başkanl1ğında verilmiş konferans, s.7. 
Ermeniler'in 24 Eylül'de başlattıkları taarruz, başında General Kazım Karabekir'in bulunduğu Doğudaki ordumuz tarafından karşılanmış, yenilen Ermeniler 6 Kasım'da mütareke teklifinde bulunmuşlardır. Sevr'den sonra 2-3 Aralık 1920 de T.B.M.M. hükümeti ve Ermenilerin taraf olduğu Gümrü Antlaşması yapılmıştır.

"Kemalist Türkiye'nin sınırlarını kabul eden ilk uluslararası anlaşma 2 Aralık 1920'de Gümrü'de Ermeni Sovyet Sosyalist Cumhuriyeti temsilcileriyle imzalandı. Az sonra Sovyet Sosyalist Cumhuriyetler Birliği ile 16 Mart 1921'de imzalanan bir diğer antlaşma ile sınırlar kabul edildi ve genişletildi. Bu antlaşmanın maddeleri 1877 de Çarlık Rusya'șının Osmanlı Imparatorluğu'ndan savaşta aldığı Kars, Ardahan ve Artvin illerinin Türkiye'ye iadesini öngörüyordu. Bu başarı Mustafa Kemal'in Türkiye'nin bölünmez bir parçası olarak kabul ettiği topraklar üzerinde padişah VI. Mehmet'in temsilcileri tarafından 10 Agustos 1920 'de imzalanan Sevr Antlaşması uyarınca işgal bölgeleri oluşturan iki süper güç ile yapılan anlaşmalarla tamamlandi.

13 Mart 1921 tarihinde Roma hükümeti ile varılan uzlaşma sonucu, Italya, Antalya ve Konya illerini işgalden vazgeçiyordu ve Temmuz ayından önce askerlerini geri çekmeyi taahhüt ediyordu. 20 Ekim tarihinde, Fransa ile de benzer bir anlaşmaya varıldı. Bu uzlaşma Türkiye'ye Toroslarda bulunan askerlerini Batı Anadolu cephelerine kaydırma imkanı veriyordu. Fransız himayesinde bulunan Suriye ile ilgili iki tarafın da kabul ettiği geçici bir sınır sağlıyordu (Bu sınır 1928'de Cizre anlaşmazlığına bulunan çözüm ve 1939'da Iskenderun sancağının Türkiye'ye verilmesi ile kesinlik kazand1)."?

Yabancı yazar oldukça teferruatlı adı geçen Antlaşmalardan bahsediyor, bir de Mustafa Kemal'in ağzından dinleyelim:

"Efendiler, Gümrü Muahedesi hükümet-i milliyenin aktettiği ilk muahededir. Bu muahede ile düşmanlanmızın hayalhanesinde kendisine ta Harşit vadisine kadar olan Türk ülkeleri bahşedilmiş olan Ermnistan, Osmanlı Devletinin 1877 seferiyle kaybetmis olduğu yerleri bize, hükümet-i milliyeye terkederek dava haricine çıkarılmıştır. Şarkta, vaziyetlerde mühim tebeddül olması yüzünden, bu muahede yerine, bilahare aktolunan 16 Mart 1921 tarihli Moskova ve 13 Teşrinievvel 1921 tarihli Kars Muahedeleri kaim olmuştur.

Efendiler, umumi mıntıka itibariyle, temas halinde bulunduğumuz Gürcistan ile cari muamele ve münasebet hakkında da kısa bir malumat vereyim." 8

Gümrü Antlaşması'nı 6-10 Ocak 1921 Birinci İnönü Savaşı, 21 Şubat-12 Mart 1921 Londra Konferans1, 16 Mart 1921 Moskova Antlaşmas1, 28 Mart-1 Nisan 1921 İkinci İnönü Savaş1, 10-25 Temmuz Kütahya-Eskişehir savaşları, 23 Ağustos-13 Eylül 1921 Sakarya Savaşı, 20 Ekim 1921 Ankara Anlaşması takip etmiştir.

7. Jean-Louis Bacque-Grammont, Jean Paul Roux, a.e. s.46.

8. Gazi Mustafa Kemal, a.e. s.654. 
"Çekilmek nazariyesini kırmak için memleket müdafaasını başka bir tarzda ifade ve bu ifademde 1 srar ve şiddet göstermeği faydalı ve müessir buldum. Dedim ki: "Hatt-1 müdafaa yoktur, sath-1 müdafaa vardır. O satıh, bütün vatandır. Vatanın, her kanı̧ toprağı, vatandaşın kanıyla 1slanmadıkça, terkolunamaz. Onun için küçük, büyük, her cüz-i tam, bulunduğu mevziden atılabilir. Fakat küçük, büyük her cüz-i tam, ilk durabildiği noktada, tekrar düşmana karşı cephe teşkil edip muharebeye devam eder. Yanındaki cüz-i tamın çekilmeğe mecbur olduğunu gören cüz-i tamlar, ona tabi olamaz. Bulunduğu mevzide nihayete kadar sebat ve mukavemete mecburdur".

Işte ordumuzun her ferdi, bu sistem dahilinde, her hatvedeazami fedakarl1ğını göstermek suretiyle, düssmanın faik kuvvetlerini imha ederek, yıpratarak nihayet onu, taarruzuna devam kabiliyet ve kudretimden mahrum bir hale getirdi.

Muharebe vaziyetinin bu safhasını ihtisas eder etmez, derhal bilhassa sağ cenahımızla Sakarya nehri şarkında, düşman ordusunun sol cenahına ve müteakıben cephenin mühim aksamında mukabil taarruza geçtik. Yunan ordusu mağlup ve ricate mecbur oldu. 13 Eylül 1921 günü Sakarya nehrinin şarkında düşman ordusundan eser kalmadı. Bu suretle 23 Ağustos gününden 13 Eylül gününe kadar, bugünler de dahil olmak üzere, yirmi iki gün ve yirmi iki gece bilafasıla devam eden, Sakar Melhame-i Kübrası,. yeni Türk Devleti'nin tarihine; cihan tarihinde ender olan büyük bir meydan muharebesi misali kaydetti."

Ankara Anlaşması T.B.M.M. hükümeti ve Fransa arasında yapılmıştır. Mustafa Kemal Paşa ile Fransız temsilcisi Franklin-Bouillon arasında Ankara'da 13 Haziran 1921'de başlayan görüşmeler Sakarya Savaşı sırasında kesilmiş, 24 Eylül'de yeniden başlamış ve 20 Ekim'de anlaşma ile sonuçlanmıştır.

$\mathrm{Bu}$ anlaşma Batı devletlerinden biriyle yapıyan ilk anlaşmadır. Anlaşma gereğince güney bölgemiz Fransızlar tarafından savaşsız boşaltıldı, Gaziantep, Mersin, Adana ve çevresi kurtuldu. Suriye sınırı çizilmiş oldu.

26-30 Ağustos 1922 tarihleri arası Büyük Taarruz olmuştur. Yine Gazi Mustafa Kemal'in nutkundan bir iki satır hatırlayalım:

"Her safhasiyle düşünülmüş, ihzar, idare ve zaferle intaç edilmiş olan bu harekat, Türk ordusunun, Türk zabitan ve kumanda heyetinin, yüksek kudret ve kahramanlığını tarihte bir daha tespit eden muazzam bir eserdir.

$\mathrm{Bu}$ eser, Türk milletinin hürriyet ve istiklal fikrinin layemut abidesidir. Bu eseri vücuda getiren bir milletin evladı, bir ordunun Başkumandanı olduğumdan, ilelebet mes'ut ve bahtiyarım."10

1 Eylül 1922'de Mustafa Kemal Paşa "Ordular! İlk Hedefiniz Akdeniz'dir Îleri” emrini vermiştir. Aynı emiri Edouard Herriot'un Orient adlı eserinde aşağıdaki satırları okuyoruz:

9 Gazi Mustafa Kemal, a.e. s.826.

10. A.e. s. 2 . 
“...Hiçbir zaman çıkannı düşünmez, yiğitliğini hiç kaybetmez; Çanakkale'de mermi parçası kalbine çarpar ve saatini kırar. 1919'da büyük fedakarlık gösterir. Emirleri kısadır. 1 Eylül 1922 'de askeri birliklerine şöyle hitap eder: "Ordular Ilk Hedefiniz Akdeniz'dir, lleri!"11

9 Eylül 1922'de İzmir kurtulmuş, 18 Eylül 1922'de Anadolu düşmandan temizlenmiştir. 3-11 Ekim 1922'de Mudanya Konferansı yapılmıştır.

“Ağustos 1922'de Mustafa Kemal'in Dumlupınar Zaferi ve ardından Yunan ordusunun bozgunu, aynı yıl 11 Ekim'de Ingiltere temsilcileri ile imzalanan ve üç gün sonra Yunanistan tarafindan kabul edilen Mudanya Mütarakesi ile sonuçlandi. Bu anlaşma Yunan askerlerinin Trakya'dan derhal çekilmesini şart olarak ileri sürüyordu. Aynı şekilde, barış imzalandığı anda, yani en kısa sürede, Ingilizlerin Istanbul ve Boğazlardan çekilmesi gerekiyordu. Bu maddeler bir yıldan önce Lozan Antlaşması (24 Temmuz 1923) ile kesinleşti. Bu son antlaşma ile Türkiye'nin uluslararası topluluğa katılması ve Kemalist hükümetin ve Ankara Meclisi'nin antlaşmayı imzalayanlar tarafından (Ingiltere, Fransa, Italya, Japonya, Yunanistan, Yugoslavya, Romanya, S.S.C.B., Bulgaristan) kesin olarak tanınmas1$\mathrm{n}$ ı sağlıyordu. Türk-Yunan sınırı ve aynı zamanda Canakkale Boğazı'nda ve Ege Denizi'nde bulunan Bozcaada ve Imroz adaları üzerinde Türkiye'nin hakimiyeti tartışmasız kabul ediliyordu. Böylece Avrupa tarafında, komşularıyla hiç bir toprak anlaşmazlığı kalmıyordu.

Anadolu'nun doğu sınırlan Ankara hükümetini tanıyan ve bundan böyle onunla ilgili iyi ilişkilerde bulunan Iran ile 16 Haziran 1922 'de belirlendi." 12

Şimdi yine Mustafa Kemal Paşa'nın nutkuyla belgeleyelim:

"29 Eylül 1922 tarihinde, bu notaya verdiğim kısa bir cevapta, Mudanya Konferansı'nı kabul ettiğimi bildirdim. Fakat Meriç Nehri'ne kadar, Trakya'nın derhal bize iadesini talep ettim. 3 Teşrinievvelde in'ikadı münasip olacağını söyledim. Mudanya Konferansı'na, Başkumandanlık namına salahiyet-i fevkaladeyi haiz olmak üzere Garp Cephesi Ordulan Kumandanı Ismet Paşa'yı, murahhas tayin ettiğimi tebliğ ettim. Bu notaya hükümetçe de 4 Teşrinievvel 1922 tarihli mufassal bir cevap verildi."13

3-11 Ekim 1922 tarihleri arasında T.B.M.M. hükümeti ile İngiltere, Fransa, İtalya'nın (Yunanistan Konferansa girmemiștir) katılımıyla gerçekleşen Mudanya Konferansı'nda aşağıdaki şartlar öne sürülmüştür:

- Doğu Trakya on beş gün içinde Yunanlılarca boşaltılacaktır.

- Trakya, boşaltıldıktan sonra otuz gün içinde Türk yönetimine teslim edilecektir.

- Türkler, barış (Lozan) Konferansı sonuna kadar Trakya'da 8.000 jandarma bulundurabileceklerdir.

- Istanbul ve Boğazlar da Türk yönetimine bırakılacak; ancak ttilaf kuvvetleri barışın imzasına kadar Istanbul'da kalacaklardır.

11. Edouard Herriot, Orient. Hachette. Paris 1934, s.98.

12. Jean-Louis Bacque-Grammont, Jean Paul Roux, a.e. s.47.

13. Gazi Mustafa Kemal, a.e. s.904. 
Osmanlı Devleti'nin sona ermesi 30 Ekim 1922, Saltanatın kaldırılması 1 Kasım 1922 tarihine rastlar.

"Bu müssterek davet keyfiyeti, salatanat-1 şahsiyenin lağvı muamelesini, kat'i olarak intaç etti. Filhakika 1 teşrinisani 1922 tarihli kanun mucibince, hilaget ile salatanat biribirinden tefrik olundu. Iki buçuk seneyi mütecaviz bir zamandan beri fiilen icra-yi hükmeden salatanat-1 milliye teyit olundu. Hilafet, sarih bir hukuka malik olmaksızın bir müddet daha bırakıldı."14

1 Kasım 1922 günü Saltanatın T.B.M.M tarafından kaldırılması üzerine, 4 Kasım günü İstanbul'da Tevfik Paşa kabinesi istifasını vermiş; daha Ekim ayı ortalannda İstanbul'a gelmiş olan T.B.M.M. temsilcisi Refet Paşa, İstanbul'da hükümete elkonulduğunu Ankara'ya bildirmişti.

Mudanya Mütarakesi imzalandıktan sonra, Yunanlılar, 15 Ekim'de yürürlüğe giren mütarekeye göre, Trakya'yı boşaltmaya başlamışlar, Trakya'nın T.B.M.M. hükümetine teslimi Kasım 1922 sonunda tamamlanmıştır.

Lozan Antlaşması'nın imzası 24 Temmuz 1923'de yapılmıştır.

"Lozan Konferansı içtima-1 umumisi 21 Teşrinisani 1922 tarihinde vukubulmuştur. Bu Konferansta, Türkiye Devleti'ni Ismet Paşa Hazretleri temsil etti. Trabzon Meb'usu Hasan Bey ve Sinop Meb'usu Riza Nur Bey, Ismet Paşa riyyasetindeki heyet-i murahhasayı teşkil ediyordu.

Heyet-i murahhasamız, Teşrinisani 1922 iptidalarında, Lozan'a gitmek üzere Ankara'dan müfarekat etti.

Efendiler, iki devirden ibaret olup sekiz ay devam eden Lozan Konferansı ve neticesi dünyanın malumu bulunan bir keyfiyettir."15

Lozan Antlaşması'na, T.B.M.M. hükümeti ile İngiltere, Fransa, İtalya, Japonya, Yunanistan, Romanya, Sirp-Hirvat-Sloven Devletleri taraf olmus ve Amerika Birleşik Devletleri, Sovyet Rusya, Bulgaristan, İspanya, İsveç, Norveç, Hollanda zaman zaman konferansa katılmışlardır. Konferans ile ilgili önemli hususlar şu şekildedir:

- Sınırlar: Türkiye'nin (Hatay hariç) bugünkü sınırları. Bir Ermenistan devleti kurulması tasarısı söz konusu edilmemiştir.

- Kürdistan: Söz konusu edilmemiştir.

- İktisadi nüfuz bölgeleri: Söz konusu edilmemiştir.

- Istanbul: Söz konusu edilmemiştir.

- Uyrukluk: Söz konusu edilmemiştir.

- Adli kapitülasyonlar: Hiç bir kayıt konulmamıştır.

- Azınlıkların korunması: Misak-1 Milli esaslarına göre yalnız gayrimüslimler için Birinci Dünya Savaşı'ndan sonra yapılan uluslararası antlaşmalarda bulunan hükümler.

14. Gazi Mustafa Kemal, a.e. s. 910

15. A.e. s. 934 
- Askeri hükümler: Boğazlar için konulan, 1936 Montreux Sözleşmesi'nde kaldırılan askersiz bölge (sadece 12000 asker).

Lozan Konferansı'ndan sonra Ankara'nın başkent olmasına karar verilmiştir. Ankara'nın tercih sebebini Andre Siegfield şöyle anlatıyor:

“Constantinople eski Türkiye'nin en ünlü başşehriydi. O Türkiye ki sadece Türklerden değil, Yunanl, Ermeni ve işte ne bileyim birçok milletlerin insanlarından oluşuyordu. Türkler askeri ve idari kuvveti, devlet düzenini, takas etmekten ziyade inşa etmesini bilen dürüst insanları temsil ediyordu. Diğerleri tüccarlar, tanıdıkları birçok etkili kişiler olan, tamamen denizle ilgili o harika Akdeniz medeniyetine ait insanlardı. Osmanlı Imparatorluğu'nun çöküşüyle, Türkiye bu yabancılara bağımlı hale gelmişti. Milli bir temel oluşturmak için, Atatürk Büyüleyici Boğaz kıyılarını bırakarak, idari ve politik başşehrin Anadolu'nun tam ortasında olmasını istedi.

Kastilya'nın yüksek yaylasanı biliyorum. Moğolya'yı aynı şekilde Andes yüksek yaylalarını gezdim. Bir çok memleket başşehirlerinin, İspanya'da Madrid, eski Peru'da Huancayo, deniz kenarı yerine iç kısımlarda, tercihan yüksek irtifada olmalarını düşünmüsslerdir. Iste Ankara'nın durumu da buna benzer. Orada maddeten ve manen Istanbul'dakinden daha başka bir hava teneffüs edilir. Toprakla uğraşan Moğolların Asya'sıdır, fakat geçmiş Yunan hatıraları hâlâ Ankara Kalesi'nde mevcuttur. Bununla beraber çağdaş başşehri yaratan ilham, özellikle çağdaş bir ilhamdır ve bu harika şehir güçlü bir iradenin ifadesi olan bu şehir, bir XX. yüzyıl başşehridir."16

Gazi Mustafa Kemal'in kendi sözleriyle yabancı yazanı sözlerini doğruluyoruz.

"Hariciye Vekili Ismet Paşa: 9 Teşrinievvel 1923 tarihli bir maddei kanuniye Meclise teklif etti. Zirinde daha ondört kadar zatın imzası olan bu teklifi kanuni 13 Teşrinievvel 1923 tarihinde uzun müzakere ve münakaşalardan sonra ekseriyeti azime ile kabul edildi. Maddei kanuniye şudur: "Türkiye Devletinin makarn idaresi, Ankara şehridir."17

29 Ekim 1923 tarihinde Cumhuriyet ilan edilmiştir. Bakalım K.S. Chantich-Chandan Cumhuriyetle ilgili ne diyor:

"Bu gün Türk Devletinin hayatı bütünüyle ele alındığında eskisinden tamamen farklı bir manzara ortaya çıkar. Savaş sonrası Türkiye'de meydana gelen saltanatın kaldırilması ve Cumhuriyetin ilaniyla son bulan devrim, Osmanlı Devletinde hiç duyulmamıs politik, sosyal ve dini değişimlere sebep oldu... Bu günün Türkiye'sinde bütün yeniliklerin ilham kaynağ1 Mustafa Kemal Paşa'dır ve bu yenilikleri gerçekleştirme yollarını da o göstermistir. Yeni Cumhuriyetin yenilik dönemi Mustafa Kemal'in düsünme biçimiyle o kadar doludur ki ekonomik, sosyal, politik olsun entellektüel veya dini olsun bu büyük reformcunun kişiliği üzerinde durmadan bir

16. Siegfried Andre, Lettre-Preface a l'ouvrage de Louis Dollot, La Turquie vivante, Berger-Levraut, Paris 1957, s.10.

17. Gazi Mustafa Kemal, a.e., Cilt II, s.1060-1061. 
sorunun üzerinde konuşup tartışmak mükün değildir. Mustafa Kemal diğer adıyla Gazi, ülkenin ruhu olmuştur. Yeni Cumhuriyet, Mustafa Kemal'in fikirlerinin canlı örneğinden başka bir şey değildir." ${ }^{18}$

Gazi Mustafa Kemal Paşa'nın Cumhurbaşkanlığı'na seçildiği 29 Ekim 1923 günü T.B.M.M.'de yaptı̆̆ı konuşması Nutku'nda da yer almaktadır. Biz burada sadece bir paragrafını veriyoruz:

"Daima, muhterem arkadaşlarımın ellerine çok samimi ve sıkı bir surette yapışarak onların şahıslarından kendimi bir an bile müstağni görmiyerek çalışacağım. Milletin teveccühünü daima nokta-i istinat telakki ederek hep beraber ileriye gideceğiz. Türkiye Cumhuriyeti mes'ut, muvaffak ve muzaffer olacaktır.

Efendiler, Meclisce, cumhuriyet karan 29/30 Teşrineevvel 1923 gecesi saat 8.30 'da verildi. On beş dakika sonra, yani 8.45 'de reisicumhur intihap olundu. Keyfiyet aynı gece bütün memlekete tebliğ ve her tarafta geceyarisindan sonra, yüz bir pare top endaht edilerek ilan olundu." 19

\section{KAYNAKLAR}

Chantitch-Chandon, K.S, de miracle turc La Renaissance moderne, Paris 1929

Gentizon, Paul, Mustafa Kemal ou l'Orient en Marche. Bossard, Paris, 1929

Grammont Yean-Louis Bacque, Roux, Jean Paul, Mustafa Kemal Atatürk et la turquie nouvelle, Moisonneure et Larose, Paris 1982.

Herriot Edouard, Orient. Hachette, Paris 1934

Yevakhoff Alexandre, Kemal Atatürk. Tallandier, Paris 1989.

Kemal Gazi Mustafa, Nutuk-Söylev, Türk Tarih Kurumu Basımevi, Ankara 1989, cilt I,II.

Roux, Jean-Paul, La Turquie. Geographie. Economie. Histoire Civilisation et Culture. Payot, Paris 1953.

Sarraut Albert, Von Ambassade en Turquie, 27 Şubat 1953 te Belediye Başkanlığında verilmiş Konferans.

Siegfried, Andre, Lettre - Preface a l'ouvrage de Louis Dollot, La Turquie vivante, Berger-Levraut, Paris 1957.

\section{YAYIN LISTESI}

\section{MAKALELER}

1. Ünlü Fransız Yazan Flaubert'in Gözü ile Istanbul, Meydan Aylık Fikir ve Sanat Dergisi, Haziran 1982, Sayı 606-88., Sayfa 53-55.

18. K.S. Chantich-Chandon, Le miracle turc, La Renaissance moderne, Paris 1929 , giriş s.7.

19. Gazi Mustafa Kemal, a.e. s.1084. 
2. Ünlü Fransız Yazarı Flaubert'in Türkiye Hatıraları Istanbul Camileri, Meydan Aylık Fikir ve Sanat Dergisi, Ağustos 1982, Sayı 608-90, Sayfa 48-50.

3. Ünlü Fransız Yazarn Flaubert'in Gezip de Görmediği Istanbul Camileri, Meydan Aylık Fikir ve Sanat Dergisi, Eylül 1982, Sayı 609-91, Sayfa 44-45.

4. Ünlü Fransız Yazarı Flaubert'in Türkiye Hatıraları Ayasofya'nın Tarihçesi, Meydan Aylık Fikir ve Sanat Dergisi, Ekim 1982, Say1 610-92, Sayfa 44-46.

5. Ünlü Fransız Yazarı Flaubert'in Türkiye Hatıraları Istanbul Mezarlıkları, Meydan Aylık Fikir ve Sanat Dergisi, Aralık 1982, Sayı 612-94, Sayfa 52-53.

6. Kültür Ilişsileri ve Milli Kültürrümüzün Tanıtılmast, Milli Kültür, Ekim 1982, Sayı 36, Sayfa 13.

7. Gustave Flaubert'in Istanbul Çarşıları Hakkındaki Intibaları, Milli Kültür, Sayı 43, Sayfa 59-60.

8. Ünlü Fransız Yazarl Flaubert'in Istanbul Intibaları ve Milli Kültürümüz, Kültür ve Turizm Bakanlığı, I. Milli Kültür Şurası, 23-27 Ekim 1982, "Kurum Temsilcisi Bildirileri, Kişisel Bildiri Özetleri ve Metinleri”, Ankara, 1982.

9. Ingiliz Yazar Miss Pardoe'nun Gözüyle Küçüksu Çeşmesi, Türk Kültürü, Ocak 1985 , Say1 261, Sayfa 41-42.

10. Yabancı Gözüyle Boğaziçi'nde Türk Evleri, Milli Kültür, Temmuz 1985, Sayı 49, Sayfa 27-28.

11. Gustave Flaubert'in Gözüyle Haliç Kıyıları, Türk Edebiyatı, Eylül 1985, Sayı 143, Sayfa 30-32.

12. Gustave Flaubert'in Hayalindeki Doğu, Milli Kültür, Eylül 1985, Sayı 50, Sayfa 1524.

13. Gustave Flaubert'in Gözüyle Boğaziçi, Türk Edebiyatı, Ekim, 1985, Sayı 144, Sayfa 64-66.

14. On Kasım, Milli Kültür, Aralık 1985, Sayı 51, Sayfa 1.

15. Gustave Flaubert'in Dervişler Hakkındaki Intibalar, Türk Edebiyatı, Kasım 1986, Sayı 157, Sayfâ 52-53.

16. Ortaçă̆, XVI, XVII, XVIII ve XIX nсu Yüzyıllarda Fransız Doğu Seyyahlarına Kısa Bir Bakıs, Milli Kültür, Eylül 1986, Sayı 54, Sayfa 46-54.

17. Ingiliz Yazar Miss Pardoe'nun Gözüyle Küçüksu Çeşmesi, A.Ü.Dil ve Tarih Coğrafya Fakültesi Dergisi, Cumhuriyetin 60. Yıldönümü Armağanı-ayrı basım, 1987.

\section{KITAPLAR}

18. Adolphe

Benjamin Constant

Fransızca'dan Türkçe'ye çeviri 
Kültür ve Turizm Bakanlğı Yayınları: 616

Tercüme eserler Dizisi: 43, 1985.

\section{Kırk Hadis}

Prof.Dr. Abdülkadir Karahan

Türkçe'den Fransızca'ya çeviri

Kültür ve Turizm Bakanlığı Yayınlan: 621

Sanat Eserleri Dizisi: 7, 1985.

20. Unlü Fransız Yazar Gustave Flaubert'in Doğu Seyahatinin La Tentantion de Saint Antoine'in Son Baskısı Üzerindeki Etkileri Yöre Matbaası, 1987.

21. Representation Of Woman In French Literature Yöre Matbaası, 1987.

22. Romanticism and Historical Novel In France and England Toraman Matbaacilik, 1987.

23. Jean Alcard, Vie Et Oeuvres Ofset Fotomat, 1987.

24. Jean Aicard Et La Chanson De L'Enfant Semih Ofset Matbaacılık Ltd.Şti., 1988.

25. Jean Atcard Et Les Poemes De Provence Semih Ofset Matbaacilık Ltd.Şti., 1988.

26. Jules Claretie Et Les Figures De Femmes

- Dans Mademoiselle Cachemire, Robert Burat, Madeleine Bertin Semih Ofset Matbaacılık Ltd.Şti., 1988.

27. Realistic Reactions In France and England Semih Ofset Matbaacılık Ltd.Şti., 1989.

28. Paul Hervieu, Vie Et Oeuvres

Semih Ofset Matbaacılık Ltd.Şti., 1989.

29. Paul Hervieu Et L'amour Maternel Dans Les Tenailles, La Loi de l'homme. La Course du Flambeau Semih Ofset Matbaacılık Ltd.Şti., 1989.

30. Matmazel Noraltya'nın Koltuğ Peyami Safa

Yayın No: 48 Edebi Eserler 20

(Türkçe'den Fransızca'ya çeviri, 313 sayfa)

"Le Fauteuil De Mademoiselle Noralia" Ankara, 1994.

31. Beş Şehir

Ahmet Hamdi Tanpinar

Kültür Bakanlğı Yayınları: 1189

Klasik Türk Eserleri Dizisi: 7 
(Türkçeden Fransızca'ya çeviri, 386 sayfa)

"Coni Villes"

Ankara, 1994.

\section{Türk Masallart-Cilt I}

Hazırlayan Naki Tezel

Kültür ve Turizm Bakanlığı Yayınları: 632

Gençlik ve Halk Kitaplanı Dizisi: 9

(Türkçe'den Fransızca'ya Çeviri, 101 sayfa)

"Contes Choisis Turcs"

Ertem Matbaacilik, Ankara, 1994.

33. Essai Sur François Mauriac D'Apres Quatre De Ses Romans

Le Mystere Frontenac, Therese Desqueyroux, Le Baiser au lepreux, Genitrix Akçă̆, Basım Yayım Pazarlama A.Ş. Ankara, 1994

Profesörlük Takdim Calısması. 